\title{
Morphological variation and differential susceptibility to herbivory in the tropical brown alga Lobophora variegata
}

\author{
Loren D. Coen ${ }^{1, *}$, Christopher E. Tanner ${ }^{2, * *}$ \\ ${ }^{1}$ Department of Zoology, University of Maryland, College Park, Maryland 20742, USA \\ ${ }^{2}$ Department of Botany, National Museum of Natural History, Smithsonian Institution, Washington, D.C. 20560, USA
}

\begin{abstract}
The tropical brown alga Lobophora variegata (Lamouroux) Womersley has 3 distinct morphological forms (ruffled, decumbent and encrusting) along the Belizean barrier reef. These forms are commonly associated with habitats that differ in environmental characteristics and herbivore abundance. Previous research into among-habitat variation in plant susceptibility to herbivores has focused on interspecific comparisons; here we emphasize intraspecific variation. Field (fish) and laboratory (crab) experiments compared grazing on L. variegata forms with 2 other frondose algae of the same family (Dictyotaceae), the highly palatable Padina boergesenii and the unpalatable Stypopodium zonale. Transplant feeding studies were conducted in several reef habitats to determine if these forms differed in their susceptibility to fish herbivory. Significantly different susceptibilities to grazing among L. variegata forms for both fishes and crabs were observed. Preferences of fish and crabs were similar (from most to least preferred): Padina $=$ ruffled Lobophora = encrusting Lobophora $\gg$ decumbent Lobophora $=$ Stypopodium. The distribution of ruffled and decumbent forms appears to be related to the intensity of fish grazing normally encountered in their habitats and their differential susceptibility to herbivory. The encrusting form is common in areas with high fish and sea urchin herbivory, despite being susceptible to fish grazing when removed from the substrate. The presence of this form in areas of intense grazing pressure is probably related to its encrusting habit. We suggest that the distributions of these forms, their growth morphologies and potential defenses are in some measure related to differential grazing intensities among habitats. Form variation and habit may represent an important evolutionary strategy for tropical algae when herbivory is locally intense but patchy.
\end{abstract}

\section{INTRODUCTION}

Herbivores have exerted an important selective pressure on plants since the early Paleozoic (Garrett 1970, Steneck 1983) and a considerable literature examines the interactions among plants and herbivores in both terrestrial and aquatic systems (e.g. Rosenthal \& Janzen 1979, Lubchenco \& Gaines 1981, Gaines \& Lubchenco 1982, Crawley 1983, Rhoades 1985). In tropical regions, herbivorous fishes comprise a dominant component of the plant-feeding guild on reefs (e.g. Gaines \& Lubchenco 1982, Hay 1984b, Lewis 1986). Together with sea urchins (e.g. Lawrence 1975,

\footnotetext{
Present addresses:

- Marine Environmental Sciences Consortium and CRDI, University of South Alabama, Box 369-370, Dauphin Island, Alabama 36528, USA.

- Division of Natural Sciences and Mathematics, St. Mary's College, St. Mary's City, Maryland 20686, USA
}

Hay 1984b, Carpenter 1986), herbivorous fishes markedly affect plant abundance and species richness (e.g. Wanders 1977, Hay 1981a, 1984b, Lewis 1986), indirectly facilitate settlement and survival of corals (e.g. Dart 1972, Sammarco 1980, Lewis 1986) and affect survival of 'inferior' competitors (e.g. Vine 1974, Wanders 1977, Hay 1981a, b, 1984a, Lewis 1986, Littler et al. 1986 ).

Although grazing by sea urchins and fishes on coral reefs is often characterized as being 'intense' (Borowitzka 1981, Huston 1985), recent field experiments have demonstrated that grazing is patchy, varying considerably in frequency and intensity on both temporal and spatial scales (e.g. Hay 1981c, 1984a, Gaines \& Lubchenco 1982, Lewis \& Wainwright 1985). Paradoxically, many reef-associated macrophytes persist even under locally intense grazing pressure (e.g. Hay 1981a, c, 1984a, Littler et al. 1986, Lewis et al. 1987). This apparent difference in plant susceptibility 
to herbivory may reflect inherent deterrents (structural or chemical) or refuges in time and space (reviewed in Lubchenco \& Gaines 1981, Gaines \& Lubchenco 1982, Littler et al. 1983a, b, 1986, Hay 1984a, Lewis et al. 1987).

For terrestrial plants, secondary metabolites have long been implicated in herbivore deterrence, and have been incorporated into a theoretical framework based on extensive empirical studies conducted over a broad taxonomicrange (e.g. Rosenthal \& Janzen 1979, Rhoades 1985). Several studies (reviewed in Crawley 1983) have revealed ecotypic variation in structural and chemical defenses within species resulting from polygenic variation, and/or inducible phenotypic responses to herbivore pressure (Rhoades 1985). For marine plants, chemical and structural deterrents to herbivory have been explored only recently (e.g. Littler \& Littler 1980, Gaines 1985, Hay \& Fenical 1988 and references therein). Intraspecific variation in defensive traits has largely been neglected for marine algae until recently (see Lewis et al. 1987, Hay \& Fenical 1988 and references therein), except for temperate species with alternating heteromorphic generations (e.g. crustose and erect stages; Lubchenco \& Cubit 1980, Slocum 1980).

Lobophora variegata (Lamouroux) Womersley (Dictyotales, Dictyotaceae) is a widely distributed tropical to warm-temperate seaweed (Womersley 1967) that is ideally suited for investigations of intraspecific variation in defensive traits. In the Caribbean, it is an ecologically important species in terms of both coverage and biomass. It lives intertidally (Taylor 1960) to more than $90 \mathrm{~m}$ (Littler et al. 1985). L. variegata has a range of morphological forms, often associated with different habitats (Lawson \& John 1982, Norris \& Bucher 1982, Allender \& Kraft 1983, Littler et al. 1985 , de Ruyter van Steveninck \& Breeman 1987a, b, de Ruyter van Steveninck et al. 1988a, b). This habitatrelated morphological variation is coupled with conflicting observations on the susceptibility of $L$. variegata to herbivory (Table 1); these suggest that herbivores may play a role in the selection and maintenance of L. variegata forms.

Three morphological forms of Lobophora variegata occur in Belize (Norris \& Bucher 1982, Coen 1987) and elsewhere (de Ruyter van Steveninck et al. 1988b): (1) adherent crusts, (2) flat decumbent (largely non-adherent) blades and (3) erect, ruffled, often unattached blades. Each form can dominate a different reef habitat (e.g. back-reef, spur and groove zone, reef ridge, mangrove roots, adjacent Thalassia meadows; Table 2) suggesting that physical and/or biological environmental factors related to each habitat may be important in determining the distribution and morphology of each form (see also de Ruyter van Steveninck et al. 1988a). While the habitats of each form vary widely in physical
Table 1. Lobophora variegata. Conflicting observations on susceptibility to herbivory

\begin{tabular}{|c|c|}
\hline $\begin{array}{l}\text { Conclusions regarding } \\
\text { susceptibility }\end{array}$ & Reference and site \\
\hline $\begin{array}{l}\text { Readily eaten by fishes } \\
\text { (No reference to forms) }\end{array}$ & $\begin{array}{l}\text { Brawley \& Adey (1977) } \\
\text { (Jamaica) }\end{array}$ \\
\hline $\begin{array}{l}\text { Readily eaten by fishes } \\
\text { (No reference to forms) }\end{array}$ & Hay (1984a) (Belize) \\
\hline $\begin{array}{l}\text { Readily eaten by fishes } \\
\text { (No reference to forms) }\end{array}$ & Lewis (1985) (Belize) \\
\hline $\begin{array}{l}\text { Not grazed by fishes } \\
\text { (No reference to forms) }\end{array}$ & Hay (1981c) (Belize) \\
\hline $\begin{array}{l}\text { Not grazed by fishes } \\
\text { (No reference to forms) }\end{array}$ & $\begin{array}{l}\text { Hay \& Goertemiller (1983) } \\
\text { (Belize, } 2 \text { sites) }\end{array}$ \\
\hline $\begin{array}{l}\text { Not grazed by fishes } \\
\text { (No reference to forms; } \\
\text { presence of 'unusual' } \\
\text { chemistry) }\end{array}$ & $\begin{array}{r}\text { Paul \& Hay (1986) } \\
\text { (Florida Keys) }\end{array}$ \\
\hline $\begin{array}{l}\text { Eaten by Diadema } \\
\text { (Rarely eaten by fishes; } \\
\text { refers to } 2 \text { forms) }\end{array}$ & $\begin{array}{c}\text { Morrison (1988) } \\
\text { (Jamaica) }\end{array}$ \\
\hline $\begin{array}{l}\text { Readily eaten by Diadema } \\
\text { (No reference to distinct } \\
\text { forms) }\end{array}$ & $\begin{array}{l}\text { de Ruyter van Steveninck } \\
\text { \& Breeman }(1987 \mathrm{a}, \text { b) } \\
\text { (Curaçao) }\end{array}$ \\
\hline $\begin{array}{l}\text { Differences related to } 3 \text { forms } \\
\text { (crabs) }\end{array}$ & Coen (1988b) (Belize) \\
\hline $\begin{array}{l}\text { Differences related to } 3 \text { forms } \\
\text { (crabs and fishes) }\end{array}$ & Present study (Belize) \\
\hline
\end{tabular}

conditions (e.g. light, depth, exposure), one obvious biological factor that may vary among these habitats is the intensity of herbivore grazing. We investigated several questions regarding these forms of L. variegata: (1) Are the 3 forms equally susceptible to grazing under comparable herbivore regimes? (2) Does susceptibility of forms vary among different components of the herbivore guild (e.g. crabs and fishes)? (3) Can herbivory maintain the distribution patterns observed for these forms? We also speculate on the attributes that might account for differences in susceptibility of the observed forms.

\section{METHODS}

Study sites and plants. All collections and experiments were conducted at the Smithsonian Institution's Carrie Bow Cay field station, Belize, Central America $\left(16^{\circ} 48^{\prime} \mathrm{N}, 88^{\circ} 05^{\prime} \mathrm{W}\right)$ during October-November 1984 , April 1985, June-July 1985 and April 1987 (Fig. 1). See Rützler \& Macintyre (1982) and Lewis (1986) for further information on the geology, hydrology and biology of adjacent areas within the Belizean barrier reef complex. 
Table 2. Lobophora variegata. Summary of characteristics of forms used in feeding experiments, Belize

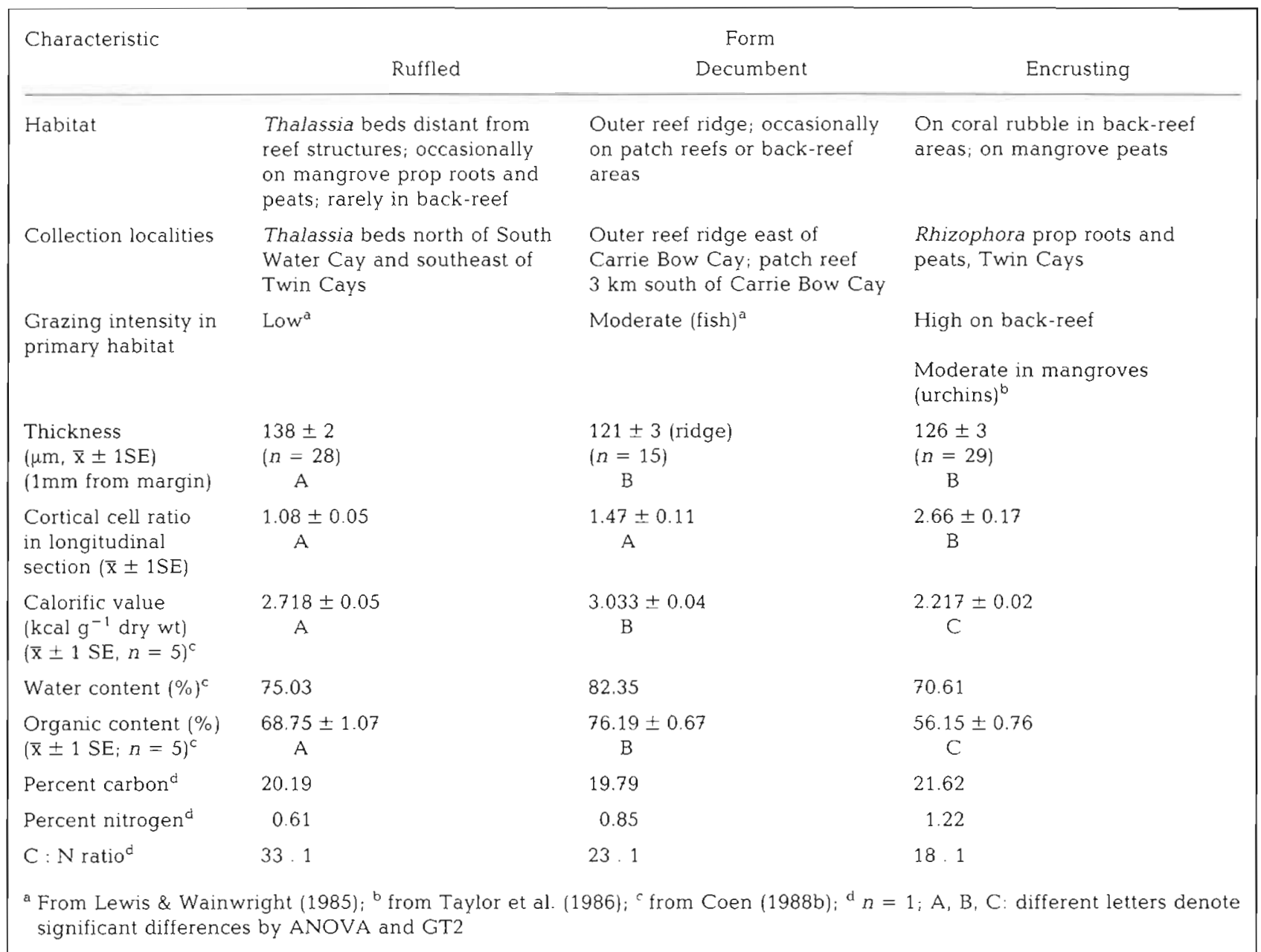

Description of Lobophora forms and other experimental plants. The ruffled form of $L$. variegata was most commonly found in and adjacent to beds of Thalassia testudinum Banks ex Koenig near South Water Cay (Fig. 1), either attached to solid substrates or as unattached individuals which rolled along the sand bottom in large aggregations. This form also attached to prop roots of the red mangrove Rhizophora mangle L. loften growing on, but not growing out of the encrusting form) in areas adjacent to Thalassia beds at Twin Cays (Fig. 1), and less commonly on Carrie Bow Cay's back-reef (Fig. 1), under corals (e.g. Acropora cervicornis Lamarck). Thalli were slightly to densely ruffled, often forming ball-like clumps as a consequence of continued lateral blade growth (Fig. 2 A). Specimens for feeding experiments were collected from Thalassia beds at the north end of South Water Cay and southeast end of Twin Cays $(0.5$ to $2 \mathrm{~m}$ depth; Fig. 1).

The decumbent form was the most abundant alga on the outer reef ridge ( $>15 \mathrm{~m}$; Fig. 1) with overlapping blades forming up to $100 \%$ cover in some areas. This form was observed also at shallower depths (1 to $2 \mathrm{~m}$ ) on patch reefs and on the back-reef, where its distribution was always patchy and generally on the lower surfaces of coral heads. Deep water specimens were relatively thin, flat and semi-circular, growing out horizontally from the substrate (Fig. 2 B, Table 2). Specimens for the feeding experiments were collected from the outer ridge (20 to $40 \mathrm{~m}$ depth), east of Carrie Bow Cay, and from a shallow water patch reef south of Carrie Bow Cay (1.5 to $5 \mathrm{~m}$ depth).

The encrusting form of Lobophora variegata (Fig. 2 C) was found in shallow water (usually 0 to $2 \mathrm{~m}$ depth) on coral rubble in back-reef areas, and on mangrove peats and red mangrove (Rhizophora mangle) prop roots in Twin Cays (Fig. 1). Thalli were often irregular, with semi-circular, marginal lobes and were attached to the substrate by short moniliform rhizoidal filaments from their lower surfaces (Fig. 2 C). The encrusting form resembled Ralfsia and other brown algal crusts, but was less firmly attached to the substrate. The 


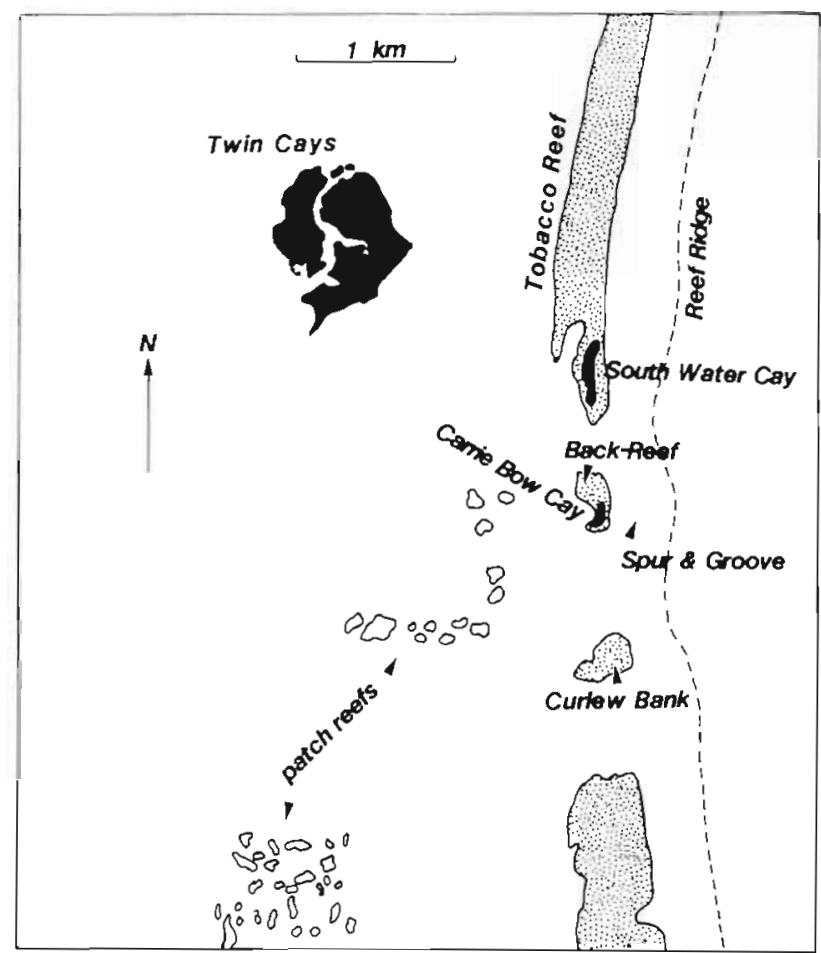

Fig. 1. Study sites, Belize, Central America

encrusting form was occasionally associated with the ruffled form along the edges of Rhizophora stands at Twin Cays and with the decumbent form on the lower shaded surfaces of heads in back-reef areas. Although the ruffled form was never observed growing out of the encrusting form, lobes of the encrusting form often produced small free lobes that resembled the decumbent form. Thalli growing on prop roots were used in the feeding experiments due to ease of removal (Table 2).
The 3 forms of Lobophora variegata (Fig. 2; ruffled, decumbent and encrusting) were collected from respective habitats (Thalassia beds, reef ridge and mangroves) for the feeding experiments and morphological comparisons. Ten or more specimens from each population used in the feeding experiments were sectioned longitudinally; thickness and cell arrangement were examined under a compound microscope. Voucher specimens of species and forms used in the experiments were deposited in the Algal Collection of the U.S. National Herbarium, Smithsonian Institution, Washington, D.C. Methods used in analyzing caloric content, percent water and percent organics are described elsewhere (Coen 1987). Carbon and nitrogen values (and ratios) were measured on an $\mathrm{HP} 185 \mathrm{~B} \mathrm{CHN}$ analyzer with an HP 3380 S integrator at the University of Delaware using standard methods. Plant material was brought back from Belize frozen in liquid nitrogen.

Padina boergesenii Allender \& Kraft was collected from the intertidal zone along the western side of Carrie Bow Cay. This species ranges in thallus thickness from 60 to $100 \mu \mathrm{m}$ (Taylor 1960, Coen 1988b). We chose $P$. boergesenu for the feeding experiments because it and other Padina species are consumed preferentially by herbivorous fishes (Hay 1984a, Lewis 1986) and may escape grazing by growing in spatial refuges or by producing an alternate herbivore-resistant morphology under high herbivory levels (Lewis et al. 1987).

Young and mature thalli of Stypopodium zonale (Lamouroux) Papenfuss were used in the feeding experiments (thickness can range from 165 to $480 \mu \mathrm{m}$; Taylor 1960, Coen 1988b). Older, thicker thalli, which tended to be leathery and highly branched, with iridescence only near the tips of branches, were col-

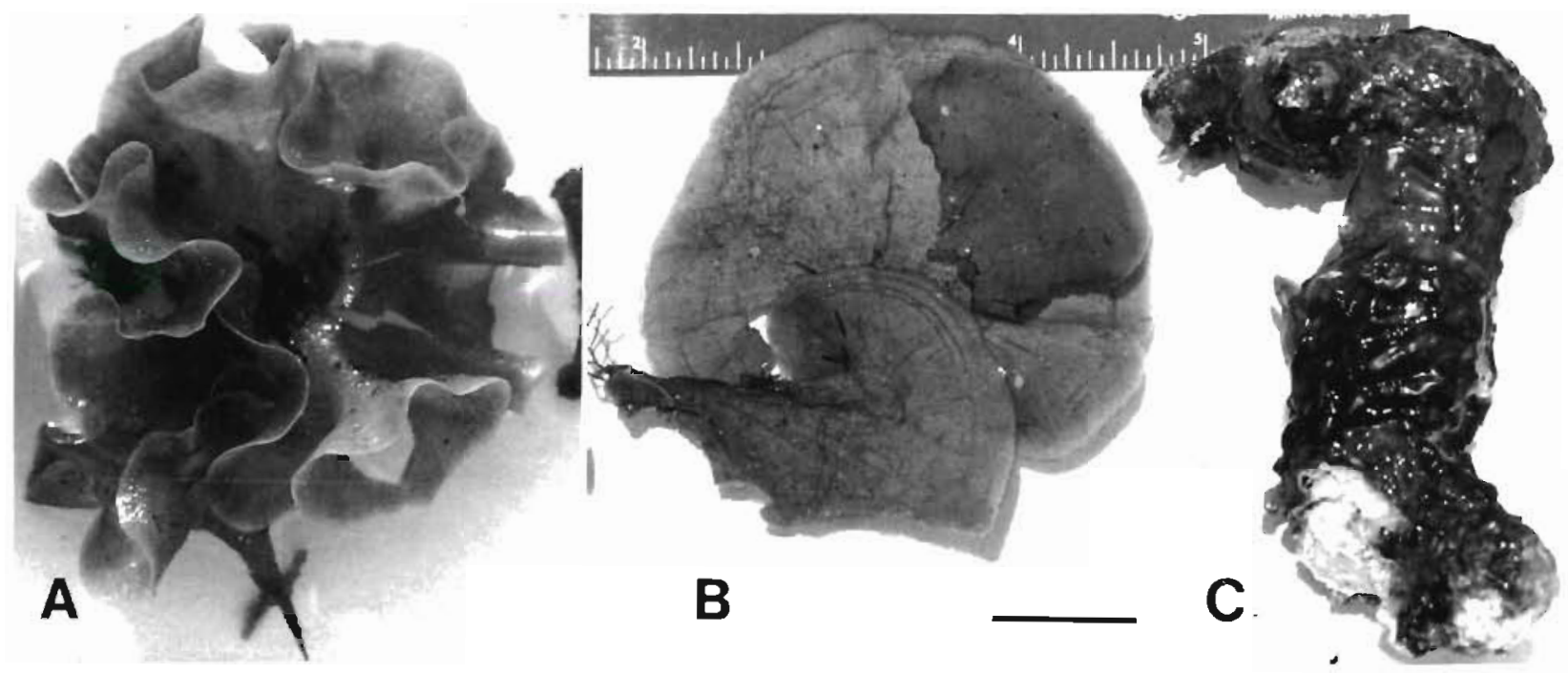

Fig. 2. Three forms of Lobophora variegata. (A) Ruffled; (B) decumbent; and (C) encrusting form (Ruler is marked in inches; scale bar $=2 \mathrm{~cm}$ ) 
lected at Curlew Bank (1 to $1.5 \mathrm{~m}$ depth). Younger thalli, which were thin and highly iridescent underwater, were taken from South Water Cut ( 3 to $5 \mathrm{~m}$ depth) between Carrie Bow and South Water Cays. We used Stypopodium zonale because: (1) it contains secondary plant compounds shown to be toxic to fish (Hay \& Fenical 1988 and references therein) and (2) it is one of the least susceptible algal species to fish grazing (Littler et al. 1986, Paul \& Hay 1986).

Crab feeding experiments. Algal susceptibilities and crab feeding rates were examined using a variety of plants in order to test whether Lobophora variegata forms were differentially grazed by Mithrax spp. relative to other plants. Two crabs (Majidae: Mithrax sculptus Lamarck and $M$. coryphe Herbst) were used to study plant susceptibility to smaller, invertebrate grazers. $M$. sculptus and $M$. coryphe are common on western Atlantic coral reefs from Florida to Brazil, where they live intertidally to $55 \mathrm{~m}$ (Coen 1988a, b). In the present study, $M$. sculptus and $M$. coryphe were collected from small individual heads of Porites porites (Pallas) in the back-reef, which is northeast of Carrie Bow Cay. Both crab species were locally abundant in complex, 3-dimensionally structured habitats (e.g. branching coral colonies as well as loose and consolidated rubble). Field experiments (Coen 1987, 1988a) have demonstrated that Mithrax spp. are primarily herbivorous and that they significantly depress algal cover on heads of Porites within localized areas.

The 3 forms of Lobophora variegata, Padina boergesenii and Stypopodium zonale were used in crab feeding experiments. Algal material without visible epiphytes was collected immediately (hours) prior to each trail. Plants of relatively similar size were used. Individual plants (mean weights $\pm \mathrm{SE}$ among species ranged from $0.15 \pm 0.01$ to $0.69 \pm 0.02 \mathrm{~g} ; n=30$ per spp.) were weighed to the nearest $0.01 \mathrm{~g}$, after shaking and patting dry with paper toweling. Individual crabs were offered a single thallus (for each species or form) in $300 \mathrm{ml}$ plastic freezer containers for $10 \mathrm{~h}(09: 30$ to 19:30 h). An experiment consisted of all replicates ( $n=$ 30 for each plant species or form) for each crab species. Night experiments were conducted with Mithrax sculptus only (20:00 to 06:00 h, $n=10$ for each plant species or form); methods were similar to day experiments, however, the encrusting form was omitted. All replicates (e.g. $n=30$, day) for a given alga or form were conducted in a single day or night. Each experiment (all replicates for all plants) was conducted over 5 to $8 \mathrm{~d}$ in fall 1984 for $M$. sculptus and summer 1985 for M. coryphe. Concurrent controls with plants $(n=5$ replicates per plant species or form for each crab species) placed in similar containers without crabs for equal times $(10 \mathrm{~h})$ were used to adjust for any net weight changes in the absence of herbivores (see
Peterson \& Renaud 1989 for a discussion of appropriate controls and analyses). Crabs were starved for a minimum of $24 \mathrm{~h}$ prior to a trial. Individual crabs were used in feeding trials only once per experiment. Detailed methodologies and results of multiple-choice discrimination experiments have been given elsewhere (Coen 1988b).

At the conclusion of each trial, individual plants were dried and re-weighed. Loose fragments were collected and weighed along with intact portions. Because we used similar sized thalli (based on estimates of area) from plants differing in morphology (i.e. mass per unit volume), net weight change (pre-weight minus postweight) was calculated rather than percent change, since percents may be sensitive to pre-weight differences within and among species (Coen 1988b). Differences in net weight change (pre-weight minus postweight) were analyzed by ANOVA using SAS (1982) after data (weight change) were square-root transformed to meet homogeneity of variances assumption (see Coen 1988 b for details).

Fish grazing experiments. Four field feeding experiments (Table 3) were conducted in order to examine feeding rates on Lobophora variegata forms relative to plant species encompassing a broad range of known susceptibilities to herbivorous fishes. Experiments were conducted in 3 habitats (Table 3 ) each differing in herbivore fish abundance and composition. Quantitative fish censuses were not conducted during our field experiments; however, sites (Table 3 ) were chosen to coincide with those employed previously in studies of fish abundances and grazing intensity (Hay 1981c, Lewis \& Wainwright 1985, Lewis 1986, Littler et al. 1986). Algae for fish grazing (feeding line) experiments were collected just prior $(<2 \mathrm{~h})$ to experiments or held in submerged mesh bags off the Carrie Bow dock for no more than 2 d. Specimens for Expts 1, 2 and 3 (Table 3) were patted dry and weighed to the nearest $0.01 \mathrm{~g}$; $0.1 \mathrm{~g}$ for Expt 4 . Similar sized (surface area) pieces of each alga were used to control for any possible differences in 'apparency' (e.g. among L. variegata forms) to visually-orienting herbivores. Weights varied with a species' (or form's) thickness and morphology. Weighed plants (Expts 1, 2 and 3) were inserted between the strands of 3-stranded polypropylene lines (total length $30 \mathrm{~m}$ per line for Expts 1 to 3 ) every $0.5 \mathrm{~m}$, alternating plants such that adjacent individuals (species or forms) on that line were never the same. Ten to 15 individual plants of each species (or form) were used in each experiment (Table 3). For Expt 4, 3 thalli of each species (or form) (total of 3 plants $\times 4$ species or form per line) were inserted into 5 replicate $3 \mathrm{~m}$ lines at $10 \mathrm{~cm}$ intervals. Feeding lines were transported to each field site in buckets of seawater and then anchored $0.5 \mathrm{~m}$ to $1 \mathrm{~m}$ above the bottom (Expts 1 to 3 ) to 
Table 3. Fish grazing experiments conducted near Carrie Bow Cay, Belize

\begin{tabular}{|c|c|c|c|c|c|c|}
\hline Expt & Date & Locality & $N^{a}$ & $K$ & Duration & Species and form \\
\hline 1 & 5 Nov 1984 & $\begin{array}{l}\text { Spur and Groove area, east of Carrie } \\
\text { Bow Cay, } 3-4 \mathrm{~m} \text { depth }\end{array}$ & 1 & 15 & $6 \mathrm{~h}$ & $\begin{array}{l}\text { Lobophora ruffled } \\
\text { Lobophora decumbent } \\
\text { Padina }\end{array}$ \\
\hline 2 & 7 Nov 1984 & $\begin{array}{l}\text { Spur and Groove area, east of Carrie } \\
\text { Bow Cay, } 3-4 \mathrm{~m} \text { depth }\end{array}$ & 1 & 15 & $24 \mathrm{~h}$ & $\begin{array}{l}\text { Lobophora ruffled } \\
\text { Lobophora decumbent } \\
\text { Padina } \\
\text { Stypopodium mature }\end{array}$ \\
\hline 3 & 10 Nov 1984 & $\begin{array}{l}\text { Reef ridge, east of Carrie Bow Cay, } \\
20 \mathrm{~m} \text { depth }\end{array}$ & 1 & 10 & $6 \mathrm{~h}$ & $\begin{array}{l}\text { Lobophora ruffled } \\
\text { Padina } \\
\text { Stypopodium young } \\
\text { Stypopodium mature }\end{array}$ \\
\hline 4 & 9 Apr 1985 & $\begin{array}{l}\text { Back-reef, north of Carrie Bow Cay, } \\
1 \mathrm{~m} \text { depth }\end{array}$ & 5 & 3 & $4 \mathrm{~h}$ & $\begin{array}{l}\text { Lobophora ruffled } \\
\text { Lobophora decumbent } \\
\text { Lobophora encrusting } \\
\text { Padina }\end{array}$ \\
\hline
\end{tabular}

minimize abrasion and exclude any potential nonswimming macrograzers (e.g. sea urchins). In Expt 4, lines were anchored directly on the sandy bottom. Field sites (Table 3) included the back-reef (Expt 4), the spur and groove area (Expts 1 and 2) of the reef east of Carrie Bow Cay and the outer reef ridge (Expt 3; Table 3). Back-reef and spur and groove areas of the Carrie Bow Cay reef have been characterized as having high levels of fish herbivory, whereas moderate to high fish herbivore abundances are typical of the outer reef ridge (Lewis \& Wainwright 1985). Lines were available to fishes for 4 or $6 \mathrm{~h}$ except for Expt 2, which was left out for $24 \mathrm{~h}$, after bad weather thwarted attempts to retrieve it. At the conclusion of Expts 1, 2 and 3, each individual plant was reweighed and net weight change calculated. For Expt 4, pre- and postweights for 3 specimens of each algal species (or form) on each line were pooled. Thalli (controls) from concurrent crab experiments were used to estimate plant weight changes unrelated to grazing (e.g. respiration and growth).

For fish grazing Expts 1 to 3, each individual thallus on a line was considered an independent replicate based upon field observations that fish generally did not move along feeding lines from one species (or form) to the next (replicates of the same species or form were separated by 1.5 to $2.5 \mathrm{~m}$ ). For fish grazing Expt 4 , pooled data from each feeding line were treated as a single replicate. Multiple comparisons on significant $(p<0.05)$ ANOVAs were performed using StudentNewman-Keuls (SNK) tests (experiment-wise error rate $p<0.05)$. All statistical analyses used SAS's (1982) GLM procedure.

\section{RESULTS}

\section{Morphological and chemical differences among forms}

Thallus thickness varied significantly (1-way ANOVA, $p<0.0001$ ) among forms with the ruffled form being significantly thicker (SAS 85; GT2 multiple comparisons test for unequal $n$ ) than the other 2 forms (Table 2). One important difference among forms was the ratio of upper cortical to lower cortical cells in longitudinal section (Table 2), reflecting variation in differentiation between upper and lower blade surfaces. Cortical cell ratio was significantly different (1way ANOVA, $p<0.0001)$ among forms with the encrusting form having a ratio significantly greater (GT2 multiple comparisons test) than the 2 other forms (Table 2). The encrusting form had well-differentiated upper and lower surfaces, with numerous rhizoids often present on the lower surface, and reproductive structures, if present, on the upper surface. The ruffled form often lacked clear differences between the 2 surfaces, with reproductive structures and numerous hairs on both surfaces. The decumbent form was intermediate between the other 2 forms. No significant differences were detected for mean number of cell layers (1way ANOVA, $p>0.08$ ) among the ruffled, decumbent and encrusting forms $(5.0,5.2$ and 5.3 cells respectively). Significant differences were detected among the 3 forms for calorific values and percent organic content (Table 2). Differences were observed also ( $n=$ 1 , values based on 2 subsamples) in percent carbon and nitrogen, $\mathrm{C}: \mathrm{N}$ ratios and percent water contents among forms (Table 2). 


\section{Crab feeding experiments}

Significant differences in consumption were observed for Mithrax sculptus (day and night experiments) and $M$. coryphe (day experiments only) among the 5 plants presented (1-way ANOVAs, $p<0.0001$; Fig. $3 A, B$ ), with grazing rates ranging over 2 orders of

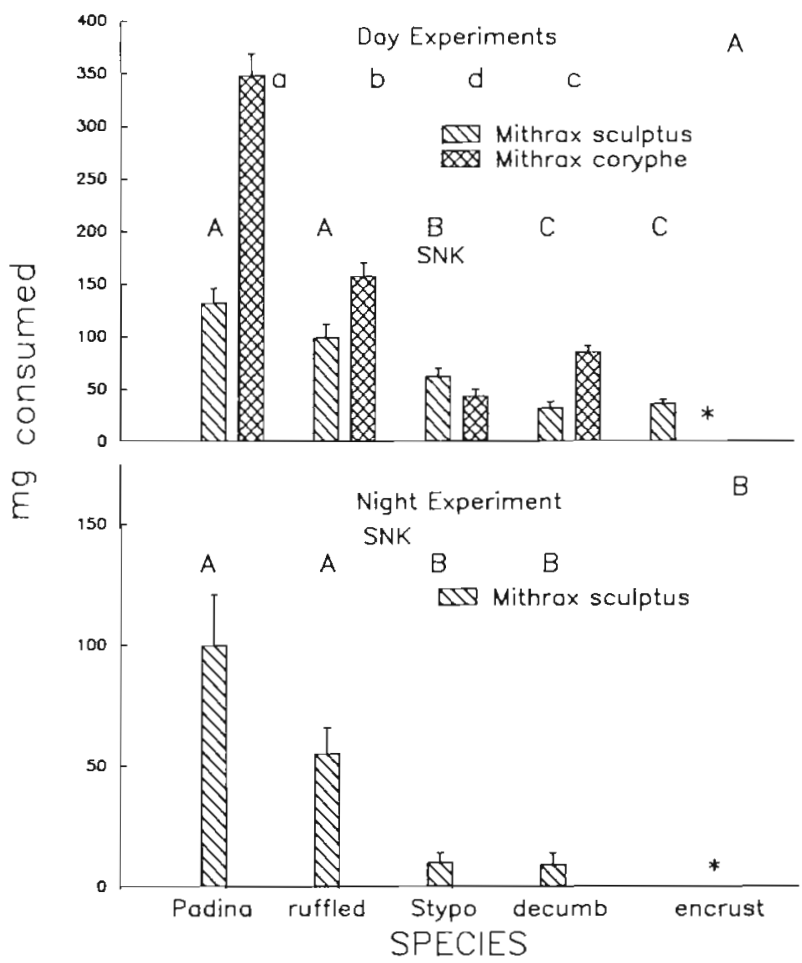

Fig. 3. Algal consumption for (A) day feeding experiments with Mithrax sculptus and $M$. coryphe and (B) night experiments with $M$. sculptus only. Means $\pm 1 \mathrm{SE}_{i} n=30$. Histograms with the same letter (upper or lower case for each species respectively) are not significantly different by SNK tests $(p>0.05)$. 'Lobophora variegata encrusting not used in (B). 'Stypopodium zonale offered in $24 \mathrm{~h}$ trials only (see Table 3). Mean \% consumption for day experiments with $M$. sculptus and $M$. coryphe respectively: (A) Padina = Padina boergesenii $(38$ and $72 \%$ ); ruffled $=$ ruffled form of $L$. variegata $(22$ and $41 \%) ;$ Stypo = Stypopodium zonale $(16$ and $15 \%) ;$ decumb $=$ decumbent form $(8$ and $38 \%)$; encrust $=$ encrusting form $(16 \%, M$. sculptus only). (B) night experiments, Padina $(83 \%)$; ruffled form $(14 \%)$; Stypopodium $(7 \%)$ and decumbent form $(8 \%)$

magnitude ( 9 to $343 \mathrm{mg} \mathrm{crab}^{-1} 6 \mathrm{~h}^{-1}$ ). Significant differences were detected among Lobophora variegata forms. In every experiment, Mithrax spp. grazed significantly more of the ruffled than the decumbent form of L. variegata (Fig. 3 A, B; SNK, $p<0.05$ ). For all control plants (grazers excluded), changes in thallus weight over the course of an experiment ( $10 \mathrm{~h}$ ) were less then the repeatability of wet weights ( \pm 2 to $4 \%$ total wet weight). This was not surprising due to the short experimental duration (hours not days) and mag- nitude of the differences among species and/or forms (e.g. mean percent consumption $7 \%$ vs near $75 \%$ of the biomass consumed).

No significant difference was observed for Mithrax sculptus (Fig. 3 A, B; day and night experiments) between Padina boergesenii and the ruffled form of Lobophora variegata or for night experiments (Fig. 3 B), between Stypopodium zonale and the decumbent form of $L$. variegata. In contrast, a significant difference was found (SNK, $p<0.05$; Fig 3 A) between these 2 low preference species in day experiments for $M$. sculptus. However, rates for both were relatively low (Fig. $3 \mathrm{~A}$, mean rates, 0.062 and $0.030 \mathrm{~g}$ $\mathrm{crab}^{-1} 6 \mathrm{~h}^{-1}$ respectively). Consumption by $M$. sculptus of the encrusting form of $L$. variegata when removed from Rhizophora mangle roots was not significantly different from that on the decumbent form (Fig. $3 \mathrm{~A}$ ).

For Mithrax coryphe there were significant differences between Padina boergesenii and the ruffled form of Lobophora variegata (Fig. 3 A, day experiments), but both were consumed at relatively high rates. As with M. sculptus (Fig. $3 \mathrm{~A}$, day experiments) there were significant differences between feeding rates on Stypopodium zonale and the decumbent form of $L$. variegata (Fig. $3 \mathrm{~A}$ ), although the order of these species was reversed (Fig. $3 \mathrm{~A}$, mean rates, 0.043 and $0.085 \mathrm{~g} \mathrm{crab}^{-1}$ $6 \mathrm{~h}^{-1}$ respectively)

\section{Fish grazing experiments}

In most cases (Figs. 4 to 6), feeding preference rankings for herbivorous fishes were in concordance with results from crab studies (Fig. 3). Significant differences among Lobophora variegata forms were detected with similar results for all 3 study sites (Table 3). Whether experiments were conducted in areas with moderate or high levels of fish grazing, results were essentially the same. Grazing rates on the ruffled form (often approaching $100 \%$ ) were always significantly higher than those observed for the decumbent form (Figs. 4 to 6 ). Mean susceptibility for the ruffled form was not significantly different from that observed for Padina boergesenii except in Expt 2 (spur and groove zone, $24 \mathrm{~h}$; Fig. $4 \mathrm{~B}$ ) in which the consumption of the ruffled form exceeded that of $P$. boergesenii (Fig. 4 B).

As with the crabs (Fig. $3 \mathrm{~A}, \mathrm{~B}$ ), the decumbent form of Lobopohora variegata was ranked consistently amongst the least preferred plants in the fish feeding experiments (Figs. 4 to 6). For example, in outer reef ridge experiments (Fig. 5), the decumbent form was not significantly different (mean loss $=14 \%$ ) from Stypopodium zonale (mean loss $=11$ and $25 \%$ eaten for mature and young plants respectively). In comparison, 


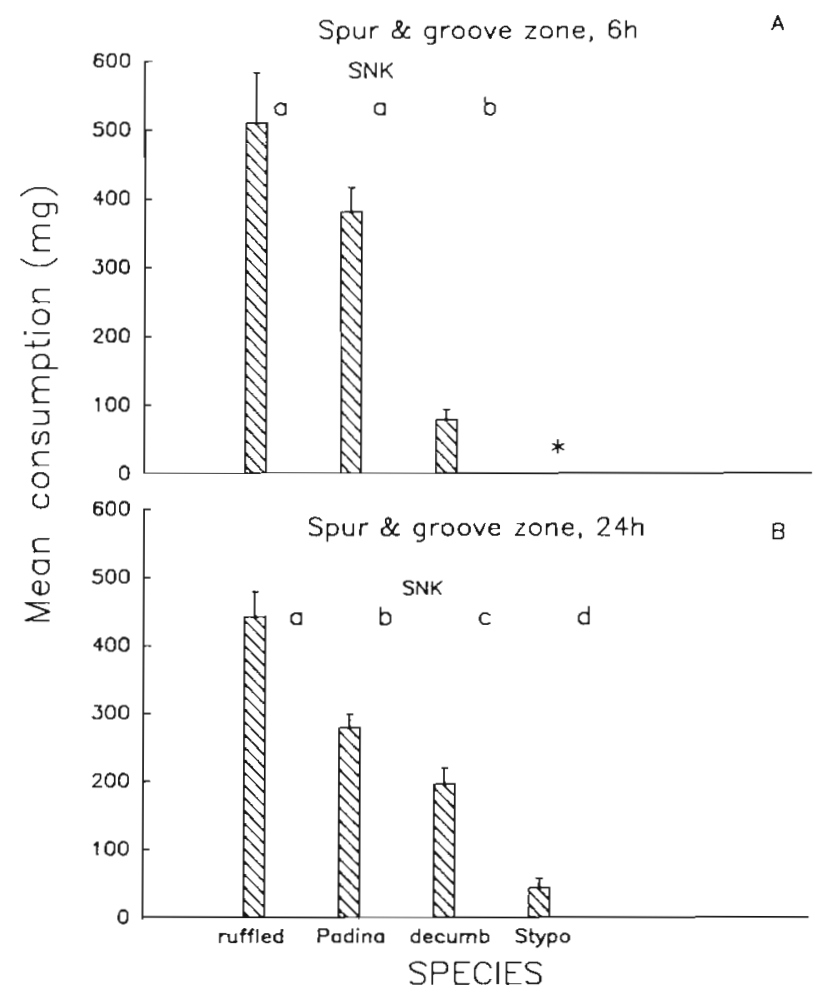

Fig. 4. Mean consumption for feeding line studies in the spur and groove zone. (A) $6 \mathrm{~h}$ and (B) $24 \mathrm{~h}$ experimental duration. ANOVAS, SNK tests and species as in Fig. $3 ;(p<0.001)$. - Stypopodium zonale offered in $24 \mathrm{~h}$ trials only (see Table 3 ). Mean \% consumption: (A) ruffled form $(89 \%)$; Padina $(91 \%)$; decumbent form (41\%). (B) Ruffled form $(90 \%)$; Padina $(88 \%)$; decumbent form $(63 \%)$; Stypopodium $(18 \%)$

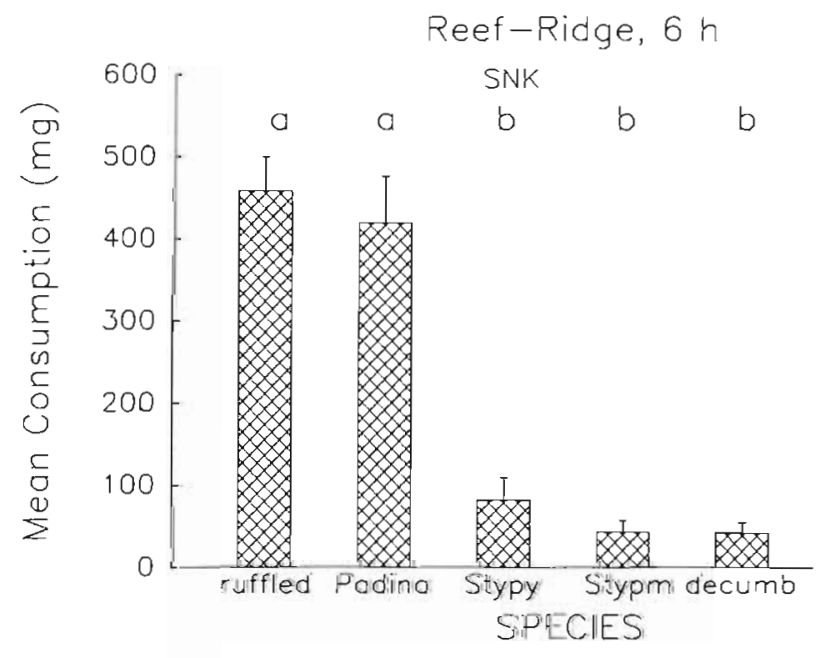

Fig. 5. Mean consumption for feeding line studies on the outer reef ridge zone. Experimental duration $6 \mathrm{~h}$. ANOVAS, SNK tests and species as in Fig. 3, except Stypy = young plants; Stypm = mature plants (see 'Methods' for explanation). Mean \% consumption: ruffled form (84\%); Padina $(84 \%)$; Stypopodium young $(25 \%)$; Stypopodium mature $(11 \%)$; decumbent form $(14 \%)$

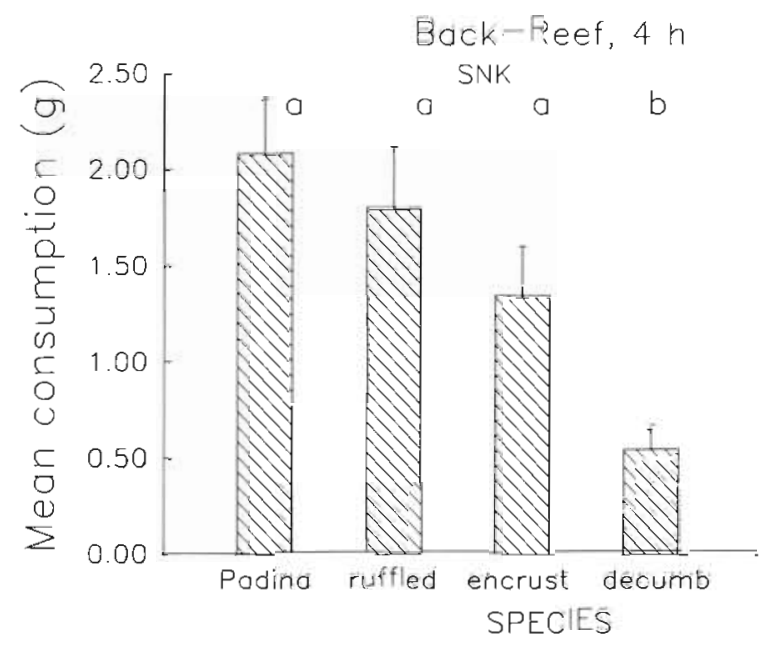

Fig. 6. Mean consumption for feeding line studies in the backreef zone, near Carrie Bow Cay. Experimental duration $4 \mathrm{~h}$. ANOVAS and SNK tests as in Fig. 3. Species and forms as in Fig. 3, except encrust $=$ crusting form of Lobophora variegata Mean \% consumption, Padina $(100 \%)$; ruffled form $(92 \%)$; encrusting form $(100 \%)$ and decumbent form $(43 \%)$

mean losses for Padina boergesenii and the ruffled form of $L$. variegata approached $85 \%$.

The encrusting form of Lobophora variegata was examined in only one experiment (Fig. 6). Its susceptibility to fish grazing ranked near Padina boergesenii (mean losses near $100 \%$ ), one of the most preferred species. This pattern contrasts somewhat to that seen with Mithrax spp. where it was not significantly different from the decumbent form (Fig. 3 A).

\section{DISCUSSION}

The goals of this study were to examine the susceptibilities of different forms of Lobophora variegata to herbivory and the potential for herbivores to maintain observed distribution patterns of the 3 different morphological forms in the Belizean reef system (Table 2). Our results clearly demonstrate that these 3 forms are differentially susceptible to fish and invertebrate grazers (Figs. 3 to 6). We further suggest that the observed distributions of these forms in Belize are related to their susceptibilities to herbivory and previously documented between-habitat variation in herbivore abundance and grazing intensity (Table 2; Hay 1981c, Lewis \& Wainwright 1985). Possible traits that may account for observed differences in susceptibility include qualitative or quantitative differences in secondary metabolites, and/or morphologies and habits (e.g. encrusting form) which are resistent or cryptic to grazers. Differences in susceptibility among forms cannot be explained by variation in thallus thickness or cell 
number (Table 2), since the ruffled form is significantly thicker than the low preference decumbent form. We do not believe that respiration/growth accounts for much individual variation over such a short duration; especially when losses exceeded $10 \%$ (near $100 \%$ in the case of Padina boergesenii; Fig. 6). Also, our experimental design controlled for any potential differences in visual 'apparency' among forms. Our results may also help to explain previous conflicting observations on the palatability of $L$. variegata (Table 1).

In Belize, the ruffled form of Lobophora variegata is often one of the most conspicuous algae in areas of relatively low grazing pressure, such as Thalassia beds found some distance from reef structure (Lewis 1985 , Lewis \& Wainwright 1985 , pers. obs.). The only specimens of the ruffled form observed in areas of high grazing pressure (back-reef, northeast of Carrie Bow Cay) were attached beneath tangled networks of Acropora cervicornis. The ruffled form ranks as one of the most susceptible algal species from Caribbean reef habitats (cf. Padina boergesenii; Hay 1981c, 1984a, Lewis 1985, 1986, Paul \& Hay 1986, Lewis et al. 1987. Coen 1988b). It was observed only in habitats with predictably low levels of fish grazing, a pattern which has been noted for other highly palatable algal species (Hay 1981a, c, 1984a, Lubchenco \& Gaines 1981, Littler et al. 1983a, Lewis 1985, 1986, Taylor et al. 1986, Lewis et al. 1987).

The decumbent form of Lobophora variegata is most abundant on the outer reef ridge, a region of moderate fish herbivore pressure (Hay 1981c, Lewis \& Wainwright 1985). This form is generally absent from shallow back-reef habitats and other areas of high fish grazing intensity, although occasional specimens were observed in potential refuges, such as the lower surfaces or crevices of coral heads and under dense stands of Acropora cervicornis. The decumbent form may be among the least palatable tropical algae for both fishes and crabs (see also Coen 1988b). Its susceptibility is similar to that of Stypopodium zonale (Figs. 3 to 6), an algal species with documented chemical deterrents to fish grazing (Hay et al. 1987 and cited references). Despite its relatively low palatability, the decumbent form was grazed upon in the feeding experiments, with consumption rates in habitats of high fish grazing pressure near $133 \mathrm{mg} \mathrm{h}^{-1}$ (back-reef). This rate was over 10 times that observed in areas of moderate pressure (high spur and groove zone, $13 \mathrm{mg} \mathrm{h}^{-1}$; reef ridge, $7 \mathrm{mg} \mathrm{h}^{-1}$ ). De Ruyter van Steveninck \& Breeman (1988b) similarly observed that this form (identified from their description) from Curaçao was restricted to deep water as result of high grazing pressure in shallow water. Thus, it appears that the decumbent form, while abundant in habitats with moderate grazing pressure, is excluded from areas with high grazing pressure, or is restricted to spatial refuges in these areas.

This form may also be susceptible to grazing by sea urchins. De Ruyter van Steveninck \& Breeman (1987a, b) presented evidence that what appears to be the decumbent form of Lobophora variegata is heavily grazed upon by the sea urchin Diadema antillarum. Additional evidence comes from Morrison (1986), who noted that extracts of $L$. variegata from Jamaica deter Sparisoma (parrotfish) but not Diadema grazing. Algae with flat blade-like morphologies are often susceptible to grazing by $D$. antillarum, even for species with compounds shown to reduce their palatability to fishes (e.g. Stypopodium zonale; Littler et al. 1983a). Diadema (juveniles only) were almost never seen in the vicinity of Carrie Bow Cay except in stands of Rhizophora mangle during the period of this study.

The decumbent form from the outer reef ridge (see Table 2) is, on average, thinner than the other forms (Table 2) and, while differing slightly in texture, it appears to offer no greater physical deterrence to feeding than the highly palatable ruffled form. Crabs easily shredded all 3 Lobophora variegata forms, yet grazed very little on decumbent thalli (multiple preference experiments; Coen 1988b). Additionally, L. variegata thalli could not physically deter grazing parrotfishes. We hypothesize that secondary metabolites may decrease the palatability of the decumbent form relative to the other 2 forms (Coen, Tanner \& Targett unpubl.). Crude extracts of $L$. variegata can deter fish (form unknown; Morrison 1986), urchin and crab grazing (decumbent form at 3 to $5 \%$ wet weight; Coen \& Targett unpubl.), and unusual secondary metabolites have been reported for this species (Hay 1984a, Paul \& Hay 1986) and a Pacific congener, L. papenfussii (Gerwick \& Fenical 1982). In a study by Paul \& Hay (1986), the presence of unusual secondary metabolites in $L$. variegata from Florida was coupled with low plant susceptibility to fish grazers. It is unclear which form(s) Paul \& Hay $(1986)$ and Morrison $(1986,1988)$ employed in their analyses; however, their material was collected presumably from deep sand plains or reef slopes (Hay 1984a), both habitats where the decumbent form is most common. This uncertainty with respect to form (e.g. Morrison 1986, 1988, Paul \& Hay 1986) further emphasizes the importance of giving detailed plant descriptions and depositing curated vouchers when documenting new examples of phenotypic variation in chemistry and form (Norris \& Fenical 1985, Lewis et al. 1987).

The encrusting form of Lobophora variegata is found in shallow-water habitats with intense fish grazing, such as the back-reef adjacent to Carrie Bow Cay (Lewis \& Wainwright 1985, Lewis 1986). The encrusting form is also common on mangrove Rhizophora mangle peats and prop roots, but only in areas which 
are all but devoid of fleshy and filamentous algae. A previous study by Taylor et al. (1986) suggested that these same mangrove areas (Twin Cays, Belize) are heavily grazed by several sea urchin species. This form of $L$. variegata appears to be less susceptible to grazing by crabs, fish (Figs. $3 \mathrm{~A}$ and 6 ) and sea urchins (Morrison 1986) as a result of its encrusting (tightly adhering) habit. Attached plants seldom show signs of grazing except for lobes that have grown free from the substratum, while thalli removed from the substrate are readily eaten by fish (Fig. 6) suggesting that its palatability may more closely resemble that of the ruffled form. Reasons for the observed difference in susceptibility between crab and fish (Figs. 3 and 6) are unclear at this time. Algae with crust-like morphologies have been assumed to be resistant to herbivary (Lubchenco \& Cubit 1980, Slocum 1980, Littler et al. 1983a, b), although few studies have actually examined how crusts avoid or withstand grazing (e.g. Slocum 1980, Steneck 1982).

Morphological and chemical plant attributes that deter herbivores have been hypothesized to be costly in terms of growth and reproduction in terrestrial (e.g. Bazzaz et al. 1987) and marine plants (Hay 1981b, 1984a, Lubchenco \& Gaines 1981). Consequently, these plant attributes may be selected against by intraand interspecific competition in habitats with predictably low incidences of herbivory (e.g. Hay 1984a). Evidence for this in tropical marine algae is limited primarily to observations that species from habitats with low herbivore pressure tend to be more susceptible to grazing than species found in areas characterized by high levels of herbivory (e.g. Hay 1984a, Lewis 1985).

Variation in susceptibility has been observed in terrestrial species (reviewed in Crawley 1983), with the maintenance of resistant genotypes or phenotypes dependent on their relative fitnesses under variable herbivore regimes. In contrast, little is known about intraspecific variation in herbivore susceptibility for marine algae (see Lewis et al. 1987, Hay \& Fenical 1988 for review). Variation in secondary compounds has been documented within and among algal 'populations' (Hay \& Fenical 1988), although the consequences of this variation for individual plants is largely unexplored. Differences in morphologies of successive life history stages of a species may also be related to herbivore pressure (Lubchenco \& Cubit 1980, Slocum 1980). Within a single life history stage, herbivore pressure may induce morphological or chemical changes which alter the susceptibility of a species to herbivory (reviewed in Lewis et al. 1987, Hay \& Fenical 1988).

We believe that intraspecific differences in susceptibility of Lobophora variegata may be related to mor- phological (habit of encrusting form) and chemical (decumbent form) traits. Populations with resistant attributes are generally distributed in habitats with moderate to high fish herbivore abundance, whereas susceptible populations (ruffled form) are restricted to habitats with low fish abundances or in spatial refuges in areas of high fish grazing. Thus, it seems likely that herbivores play an important role, along with other environmental factors, in maintaining these 3 forms and their distributions in Belize and elsewhere (Morrison 1986, 1988, de Ruyter van Steveninck \& Breeman 1987 a, b 1988a, b).

Lobophora variegata is a successful tropical seaweed in terms of its distribution and abundance (Taylor 1960, Littler et al. 1985, de Ruyter van Steveninck \& Breeman $1987 \mathrm{a}, \mathrm{b})$, no doubt in part related to its ability to adapt to a wide variety of habitats and herbivore regimes. The causes of observed morphological variation in $L$. variegata are at this time unclear. This variation may be a consequence of its morphological plasticity as a direct response to grazing (de Ruyter van Steveninck \& Breeman 1987a, b, 1988a). Such changes have been observed for Padina jamaicensis which undergoes a morphological shift from a prostrate turf morphology to an erect foliose form in response to herbivore moderation (Lewis et al. 1987). However, preliminary transplant studies (Tanner unpubl,; see also de Ruyter van Steveninck \& Breeman 1988b) suggest that L. variegata forms retain their form when transplanted to other habitats or when herbivorous fishes are excluded with cages. Alternatively, these forms may represent genetically distinct ecotypes which have diverged in response to local differences in physical and/or biological (e.g. grazing pressure) environments. In either case, differences in morphology and in susceptibility to grazing have allowed these Lobophora and Padina species (Lewis et al. 1987) to adapt to a wide variety of habitats and herbivore regimes, suggesting that this may represent an important tropical algal strategy for coping with locally intense but patchy herbivory.

These results, when taken together suggest that Lobophora variegata offers a potentially useful system for addressing questions regarding the relative effectiveness and cost of herbivore defense strategies in marine algae.

Acknowledgements. We thank Drs M. Littler, J. Norris and G. Vermeij for support and stimulating discussion during all phases of this project. Special thanks to Dr K. Rützler for additional support and encouragement for all field work in Belize. Field assistance and/or logistic support were provided by $M$ Carpenter, D. Littler and R. Sims among others. We thank N. Vrolijk for the CHN analysis. Discussion and insightful editorial comments on various drafts of the manuscript were offered by J. Geller, M. Hay, K. Heck, S. Lewis, D. Littler, P. Peterson, C. Smith, N. Targett, P. Taylor and an anonymous reviewer. This research was supported by a Smithsonian 
Institution Postdoctoral Fellowship (C.E.T.) and grants from the Smithsonian Institution (L.D.C. and C.E.T.). Additional support (L.D.C.) was provided by the Department of Zoology, the Graduate School and the Computing Center, University of Maryland and the Lerner-Gray Foundation, and Sigma-Xi Grant-in-Aid of Research. This paper is contribution No. 224, Caribbean Coral Reef Ecosystems Program, Smithsonian Institution and is partly supported by a grant from the Exxon Corporation.

\section{LITERATURE CITED}

Allender, B. M., Kraft, G. T. (1983). The marine algae of Lord Howe Island (New South Wales): the Dictyotales and Cuteriales (Phaeophyta). Brunonia 6: 73-130

Bazzaz, F. A., Chiariello, N. R., Coley, P. D., Pitelka, L. F (1987). Allocating resources to reproduction and defense BioSci. 37: 58-67

Borowitzka, M. A. (1981). Algae and grazing in coral reef ecosystems. Endeavour 5: 99-106

Brawley, S. H., Adey, W. H. (1977). Territorial behavior of threespot damselfish (Eupomacentrus planifrons) increases reef algal biomass and productivity. Environ. Biol. Fish. 2: $45-51$

Carpenter, R. C. (1986). Partitioning herbivory and its effects on coral reef algal communities. Ecol. Mongr. 56: 345-363

Coen, L. D. (1987). Plant-animal interactions: ecology and comparative functional morphology of plant-grazing decapod (Brachyuran) crustaceans. Ph. D. dissertation, University of Maryland, College Park

Coen, L. D. (1988a). Herbivory by crabs and the control of algal epibionts on Caribbean host corals. Oecologia (Berl.) 75: $198-203$

Coen, L. D. (1988b). Hervibory by Caribbean majid crabs feeding ecology and plant susceptibility. J. exp. mar. Biol. Ecol. 122: 257-276

Crawley, M. J. (1983). Herbivory the dynamics of animalplant interactions. Studies in Ecology, Volume 10. University of California Press, Berkeley

Dart, J. K. G. (1972). Echinoids, algal lawns and coral recolonization. Nature, Lond. 239: 50-51

Gaines, S. D. (1985). Herbivory and between-habitat diversity: the differential effectiveness of defenses in a marine plant Ecology 66: 473-485

Gaines, S. D., Lubchenco, J. (1982). A unified approach to marine plant-herbivore interactions. II. Biogeography. Ann. Rev. Ecol. Syst. 13: 111-138

Garrett, P. (1970). Phanerozoic stromatolites: non-competitive ecologic restriction by grazing and burrowing animals. Science 169: 171-173

Gerwick, W H., Fenical, W. (1982). Phenolic lipids from related marine algae of the order Dictyotales. Phytochem. 21: 633-637

Hay, M. (1981a). Herbivory, algal distribution and the maintenance of between habitat diversity on a tropical fringing reef. Am. Nat. 118: 520-540

Hay. M. (1981b). The functional morphology of turf forming seaweeds: persistence in stressful marine habitats. Ecology 62: 739-750

Hay, M. (1981c). Spatial patterns of grazing intensity on a Caribbean barrier reef: herbivory and algae distribution. Aquat. Bot. 11: $97-109$

Hay, M. (1984a). Predictable spatial escapes from herbivory: how do these affect the evolution of herbivore resistance in tropical marine communities? Oecologia (Berl.) 64: $396-407$
Hay, M. (1984b). Patterns of fish and urchin grazing on Caribbean coral reefs: are previous patterns typical? Ecology 65 $446-454$

Hay, M. E., Fenical, W (1988). Marine plant-herbivore interactions: the ecology of chemical defense. Ann. Rev. Ecol. Syst. 19: 111-145

Hay, M. E., Fenical, W., Gustafson, K. (1987). Chemical defense against diverse coral-reef herbivores. Ecology 68: $1581-1591$

Hay, M. E., Goertemiller, T (1983). Between-habitat differences in herbivores impact on Caribbean coral reefs. In: Reaka, M. L. (ed.) The ecology of deep and shallow coral reefs. Symposia Series for Undersea Research, Vol. 1. NOAA, Rockville, Maryland, p. 97-102

Huston, M. A. (1985). Patterns of species diversity on coral reefs. Ann. Rev. Ecol. Syst. 16: 149-177

Lawrence, J. M. (1975). On the relationship between marine plants and sea urchins. Oceanogr. mar. Biol. A. Rev. 13: 213-286

Lawson, G. W., John, D. M. (1982). The marine algae and coastal environment of tropical West Africa. Beih. Nova Hedwigia $70: 1-455$

Lewis, S. M. (1985). Herbivory on coral reefs; algal susceptibility to herbivorous fishes. Oecologia (Berl.) 65: 370-375

Lewis, S. M. (1986). The role of herbivorous fishes in the organization of a Caribbean reef community. Ecol Monogr. 56: 183-200

Lewis, S. M., Norris, J. N., Searles, R. B. (1987). The regulation of morphological plasticity in tropical reef algae by herbivory. Ecology 68: 636-641

Lewis, S. M., Wainwright, P. C. (1985). Herbivore abundance and grazing intensity on a Caribbean coral reef. J. exp. mar. Biol. Ecol. 87: 215-228

Littler, M., Littler, D. (1980). The evolution of thallus form and survival strategies in benthic marine macroalgae: field and laboratory tests of a functional form model. Am. Nat. 116: 25-44

Littler, M. M., Littler, D. S., Blair, S. M., Norris, J. N. (1985). Deepest known plant life discovered on an uncharted seamount. Science 227: 57-59

Littler, M. M. Littler, D. S., Taylor, P. (1983b). Evolutionary strategies in a tropical barrier reef system: functional-form groups of marine macroalgae. J. Phycol. 19: 229-237

Littler, M. M., Taylor, P., Littler, D. S. (1983a). Algal resistance to herbivory on a Caribbean barrier reef. Coral Reefs 2: $111-118$

Littler, M. M., Taylor, P. R., Littler, D. S. (1986). Plant defense associations in the marine environment. Coral Reefs 5 $63-71$

Lubchenco, J., Cubit, J. (1980). Heteromorphic life histories of certain marine algae as adaptations to variations in herbivory. Ecology 61: 676-687

Lubchenco, J., Gaines, S. D. (1981). A unified approach to marine plant-herbivore interactions. I. Populations and communities. Ann. Rev. Ecol. Syst. 12: 405-437

Morrison, D. E. (1986). Algal-herbivore interactions on a Jamaican coral reef. Ph.D. dissertation, University of Georgia, Athens

Morrison, D. E. (1988). Comparing fish and urchin grazing in shallow and deeper coral reef algal communities. Ecology 69: $1367-1382$

Norris, J. N., Bucher, K. E. (1982). Marine algae and seagrasses from Carrie Bow Cay, Belize. In: Rützler, K. Macintyre, I. G (eds.) The Atlantic Barrier Reef Ecosystem at Carrie Bow Cay, Belize. Smithson. Contr. mar Sci. 12: 167-238

Norris, J. N., Fenical, W. (1985). Natural products chemistry: uses in ecology and systematics. In: Littler, M. M., Littler, 
D. S. (eds.) Handbook of phycological methods: ecological field methods: macroalgae, Vol. 5. Cambridge Univ. Press, Cambridge, p. 121-145

Paul, V J., Hay, M. E. (1986). Seaweed susceptibility to herbivory: chemical and morphological correlates. Mar Ecol. Prog. Ser. 33: 255-264

Peterson, C. H., Renaud, P. E. (1989). Analysis of feeding preference experiments. Oecologia (Berl.) (in press)

Rhoades, D. F. (1985). Offensive-defensive interactions between herbivores and plants: their relevance in herbivore population dynamics and ecological theory. Am. Nat. 125: 205-238

Rosenthal, G. W., Janzen, D. H. (eds.) (1979). Herbivores: their interaction with secondary plant metabolites. Academic Press, New York

Rützler, K., Macintyre, I. G. (eds.) (1982). The Atlantic Barrier Reef Ecosystem at Carrie Bow Cay, Belize. Smithson. Contr. mar. Sci. 12.

Ruyter van Steveninck, E. D. de, Breeman, A. M. (1987a). Deep water vegetations of Lobophora variegata (Phaeophyceae) in the coral reef of Curaçao: population dynamics in relation to mass mortality of the sea urchin Diadema antillarum. Mar. Ecol. Prog. Ser. 36: 81-90

Ruyter van Steveninck, E. D. de, Breeman, A. M. (1987b). Deep water populations of Lobophora variegata (Phaeophyceae) on the coral reef of Curaçao: influence of grazing and dispersal on distribution patterns. Mar. Ecol. Prog. Ser. 38: 241-250

Ruyter van Steveninck, E. D. de, Kamermans, P., Breeman, A. M. (1988a). Importance of physical and biological processes in structuring tropical intertidal populations of Lobophora variegata (Phaeophyceae). Mar. Ecol. Prog. Ser. $44: 77-84$

This article was presented by Professor C. H. Peterson, Morehead City, N. Carolina, USA
Ruyter van Steveninck, E. D. de, Kamermans, P., Breeman, A. M. (1988b). Transplant experiments with two morphological growth forms of Lobophora variegata (Phaeophyceae). Mar. Ecol. Prog. Ser. 49: 191-194

Sammarco, P. W. (1980). Diadema and its relationship to coral spat mortality: grazing, competition and biological disturbance. J. exp. mar. Biol. Ecol. 45: 245-272

SAS (1982). SAS user's guide: statistics. SAS Institute, Cary, North Carolina, USA

Slocum, C. J. (1980). Differential susceptibility to grazers in two phases of an intertidal alga: advantages of heteromorphic generations. J. exp. mar. Biol. Ecol. 46: 99-110

Steneck, R. S. (1982). A limpet-coralline alga association: adaptations and defenses between a selective herbivore and its prey. Ecology 63: 507-522

Steneck, R. S. (1983). Escalating herbivory and resulting adaptive trends in calcareous algal crusts. Paleobiology 9 : $44-61$

Taylor, P. R., Littler, M. M., Littler, D. S. (1986). Escapes from herbivory in relation to the structure of mangrove island macroalgal communities. Oecologia (Berl.) 69: 481-490

Taylor, W. R. (1960). Marine algae of the eastern and tropical and subtropical coasts of the Americas. University of Michigan Press, Ann Arbor

Vine, P. J. (1974). Effects of algal grazing and aggressive behavior of fishes Pomacentrus lividus and Acanthurus sohal on coral reef ecology. Mar. Biol. 24: 131-136

Wanders, J. B. W. (1977). The role of benthic algae in the shallow reef of Curaçao (Netherlands Antilles) III. The significance of grazing. Aquat. Bot. 3: 357-390

Womersley, H. B. S. (1967). A critical survey of the marine algae of southern Australia. II. Phaeophyta. Aust. J. Bot. 15: $189-279$

Manuscript first received: November 20, 1987

Revised version accepted: April 5, 1989 